\title{
The grazing of abundant microzooplankton causes ultrahigh seawater dimethylsulfide during Southern Ocean algal blooms
}

\author{
Miming Zhang ${ }^{1}$, Dennis Booge ${ }^{2}$, Jinpei $\mathrm{Yan}^{1}$, Chen Liang ${ }^{3}$, Yanfang $\mathrm{Wu}^{4}$, Yang $\mathrm{Bo}^{5}$, \\ Suqing $\mathrm{Xu}^{1}$, Jianjun Wang ${ }^{1}$, Jun Zhao ${ }^{6}$, Dong $\mathrm{Li}^{6}$, Jianmin $\mathrm{Pan}^{6}$, and Keyhong Park \\ ${ }^{1}$ Third Institute of Oceanography Ministry of Natural Resources \\ ${ }^{2}$ GEOMAR \\ ${ }^{3}$ Minjiang University \\ ${ }^{4}$ University of New South Wales \\ ${ }^{5}$ University of Virginia \\ ${ }^{6}$ Second Institute of Oceanography Ministry of Natural Resources \\ ${ }^{7}$ Korea Polar Research Institute
}

October 1, 2020

\begin{abstract}
Oceanic dimethylsulfide (DMS) is hypothesized to impact cloud formation and solar radiation budget at Earth's surface. Ultrahigh seawater DMS concentrations, up to hundreds of nM, have been observed in the Southern Ocean, which are commonly attributed to concurrent high phytoplankton biomass. However, phytoplankton biomass cannot fully explain the mechanism leading to those extreme values. Herein, we show the results, including seawater DMS concentrations and other biological and environmental parameters, in the water column collected in austral summer of 2015-2016 at the tip of Antarctic Peninsula. Notably, large-scale ultrahigh seawater DMS (up to $85.2 \mathrm{nM}$ and generally above $40 \mathrm{nM}$ in the upper layer) were observed only in areas with co-existing phytoplankton blooms and abundant microzooplankton (indicated by ciliates, whose abundance and biomass were above 1000 ind L-1 and $2 \mu \mathrm{g}$ L-1, respectively), suggesting the grazing of abundant microzooplankton cause the ultrahigh seawater DMS during the bloom seasons of Southern Ocean.
\end{abstract}

\section{Introduction}

Although the Southern Ocean is well known to be a high-nutrient low-chlorophyll (HNLC) area due to iron limitation (Boyd et al.2000), large-scale phytoplankton blooms occur in the open ocean and coastal areas surrounding the Antarctica (Sullivan et al. 1993; Arrigo \& van Dijken 2003). The high biomass of phytoplankton in these areas not only sustains the world's most special food-web based on krill (Atkinson et al. 2004), but also plays a critical role in regulating emissions of the important climate-active biogenic gas dimethylsulfide (DMS) (Liss et al. 2014). DMS, whose precursor dimethylsulfoniopropinate (DMSP) is formed in algal cells (Stefelset al. 2007), acts as a foraging cue for AntarcticProcellariiform seabirds (Nevitt et al. 1995). More importantly, DMS has been hypothesized to having a strong impact on the cloud formation in the marine boundary layer (MBL) (CLAW hypothesis) (Charlson et al. 1987). Despite that this hypothesis is still under debate (Quinn \& Bates 2011), evidence has indicated that DMS levels are coincident with new particle formation in the free troposphere and can actually contribute to the CCN population in MBL through entrainment (Quinn et al. 2017). The Southern Ocean is an excellent natural lab to study the DMS biogeochemical cycle and its influence on the atmospheric particles (McCoy et al. 2015), as that region is considered to be the most unpolluted area from human activity (Ayers \& Gillett 2000).

The Southern Ocean contributes more than $20 \%$ of global DMS annual emission $\left(28.1 \mathrm{Tg} \mathrm{S} \mathrm{a}^{-1}, 17.6-34.4\right.$ 
$\operatorname{Tg~S~} \mathrm{a}^{-1}$ ), which is closely related to the high seawater DMS concentrations (Lana et al. 2011). Compared with those in mid- and low- latitude regions (concentrations mainly below $5 \mathrm{nM}$ ), ultrahigh seawater DMS levels, up to hundreds of nM, were observed in the Southern Ocean during the austral spring and summer (Lana et al. 2011). And, these ultrahigh DMS concentrations were associated with the high phytoplankton biomass (Arrigo et al. 1997; Arrigoet al. 1998), which mainly occurred in marginal sea ice zone (Inomata et al. 2006; Zhang et al. 2017), coastal polynya (Tortell et al. 2011; Tortell et al. 2012; Kim et al. 2017) or even sea ice (Asher et al. 2011). However, in other similar high-productivity regions at mid- and low- latitudes, such as the eastern boundary upwelling regions (Chavez \& Messié 2009), coral reef waters (Deschaseaux et al. 2016) or coastal areas (Yanget al. 2012), the seawater DMS concentrations generally do not reach extreme values. One of the factors attributed to this difference is the low DMS removal rate caused by biological consumption, which is slower in the Southern Ocean (Del Valle et al. 2009) than that in temperate regions (Stefels et al. 2007). This inefficiency of rapid DMS removal causes its accumulation in the stratified upper water layer during the phytoplankton blooms.

Zooplankton grazing is suspected to be another key factor causing high seawater DMS concentrations. In 1986, the DMS release rate was found to be greatly increased, by approximately 24 times, because of microzooplankton grazing under controlled feeding experiments (Dacey 1986). The digestion in grazers greatly favors the transformation of DMSP from the particulate (DMSPp) to the dissolved phase (DMSPd) for further degraded by bacteria to produce DMS (Stefels et al.2007). To date, microzooplankton, such as ciliate and heterotrophic dinoflagellates (Wolfe \& Steinke 1996; Archer et al. 2001a; Archer et al. 2001b), meso- and macrozooplankton, like copepods (Tang et al. 1999) and krill (Kasamatsu et al. 2004), and even macroinvertebrates, like sea urchins (Van Alstyne \& Houser 2003) have been found to exhibit the ability to enhance DMS production through grazing. Additionally, a large-scale perturbation experiment in a Korean coastal environment indicated that the fluctuating zooplankton grazing activity in response to high partial pressure of $\mathrm{CO}_{2}$ clearly affected the DMS production (Kim et al. 2010; Parket al. 2014). However, results of field work, particularly in the Southern Ocean, is still rare. To understand the role of zooplankton grazing in regulating the seawater DMS concentrations in the Southern Ocean, we performed the measurements of seawater DMS, abundance and biomass of a critical dominating microzooplankton ciliates (Garzio \& Steinberg 2013), and other parameters, such as chlorophyll a (Chl a) and phytoplankton pigments, nutrients and water mass structures at the tip of Antarctic Peninsula during the $32^{\text {nd }}$ Chinese Antarctic Research Expedition (CHINARE). Thereby, the obtained key findings expand our understanding responsible for ultrahigh seawater DMS levels in the Southern Ocean during austral spring and summer.

\section{Materials and Methods}

\section{Cruise information}

Our measurements were performed on board the $R / V$ Xue Long during the Chinese $32^{\text {nd }}$ Antarctic Research Expedition from 31 Dec 2015 to 14 Jan 2016 (stations are shown in Figure 1 a). The cruise area was mainly located at the tip of the Antarctic Peninsula. Note that the sections D6, D5, DB, D3 and D1 were conducted during the period from the 31 Dec 2015 to 4 Jan 2016, and the sections DA and D2 were conducted during the period from 11 Jan 2016 to 14 Jan 2016.

Water column parameters

We used a Rosette sampler with Niskin bottles to collect seawater chemical and biological samples from different depths. The high-resolution physical parameters, such as salinity and temperature, were detected by an SBE 911 plus CTD profiler (Seabird, Bellevue, Washington, USA).

For the measurements of seawater DMS, $100 \mathrm{~mL}$ seawater was sampled from the Niskin bottles with a sealed brown glass bottle. The samples were stored in an insulation box and were rapidly measured within approximately $1.5 \mathrm{~h}$ ( $8.5 \mathrm{~min}$ per sample). $5 \mathrm{~mL}$ of the seawater sample was directly injected and analysed using a home-made purge and trap system coupled with a gas chromatograph and pulsed flame photometric detector (GC-PFPD). (Zhang \& Chen 2015). The detection limit of DMS was $0.05 \mathrm{nM}$. 
Seawater samples were filtered through pre-washed cellulose acetate membrane filters $(0.45 \mu \mathrm{m})$ for measuring dissolved inorganic nutrients (nitrate, phosphate, and silicate). Filtered water samples were stored at $-20^{\circ} \mathrm{C}$ before analysis. Nutrients were detected by using a continuous flow analyser (Skalar Analytical, Breda, Netherlands) following a method reported by Grasshoff et al. (2009). The detection limits were $0.1 \mu \mathrm{M}$ for nitrate, $0.1 \mu \mathrm{M}$ for silicate, and $0.03 \mu \mathrm{M}$ for phosphate, respectively.

Pigments were determined after filtering $4 \mathrm{~L}$ of seawater with glass fiber filters $(0.7 \mu \mathrm{m})$. The filters were stored in liquid nitrogen and analysed in the home lab. The details of the measurement method are described in Zhuang et al., (2016) and the references therein. The abundance of different phytoplankton species was estimated from their contributions to the total phytoplankton biomass using the CHEMTAX program (Mackey et al. 1996).

The Chl a presented here was detected by the classical method. Several hundred $\mathrm{mL}$ of seawater were filtered through a $47 \mathrm{~mm}$ Whatman GF/F firstly. The Chl a was extracted from these filters by using $10 \mathrm{~mL}$ acetone solution (90\%) for at least $24 \mathrm{~h}$ under the cool and dark conditions. Subsequently, a Turner Design Fluorometer was used to measure $\mathrm{Chl}$ a.

For the measurements of microzooplankton planktonic ciliates, $1 \mathrm{~L}$ seawater samples were collected from the Niskin bottles from different depths above $300 \mathrm{~m}$, and then fixed with Lugol's solution (1\% final concentration, $\mathrm{VV}^{-1}$ ). Each sample was concentrated to a final volume of about $50 \mathrm{~mL}$ by repeatedly settling and siphoning. The concentrated sample was then settled in an Utermöhl counting chamber for at least $24 \mathrm{~h}$, and examined using an Olympus IX 71 inverted microscope $(\times 100$ or $\times 400)$ (Liang et al. 2018). Note that aloricate ciliates and tintinnids were the dominating groups in the Southern Ocean, and generally, abundance and biomass of aloricate ciliate were much higher than those in tintinnid. Thus, in this study, the sum of aloricate ciliates and tintinnids were used to indicate the total abundance and biomass of ciliate.

Sea ice distributions, remote sensing $\mathrm{Chl}$ a and calculation of mixing layer depth

The mean sea ice distribution was calculated using the daily sea ice information at the tip of Antarctic Peninsula during the expedition (Figure 1 a). The data was obtained from the AMSR2 database in Bremen University (https://seaice.uni-bremen.de/data/amsr2) with the resolution of $3.125 \mathrm{~km}$. The evolution of Chl a distributions in the study area was obtained from the 8-day average Chl a products from the Ocean Color website (https://oceandata.sci.gsfc.nasa.gov/MODIS-Terra/Mapped/8-Day/4km/chlor_a/) with a resolution of $4 \mathrm{~km}$. The mixing layer depth was obtained from the depth at which density increased by $0.03 \mathrm{~kg} \mathrm{~m}^{-3}$ than that at $10 \mathrm{~m}$ (Figure S1).

\section{Results and discussion}

Sea ice distribution and water mass hydrography

During the cruise period, the sea ice edge retreated to the south of $62^{\circ} \mathrm{S}$ (Figure $1 \mathrm{a}$ ). All the stations were located in ice-free open waters, and only two stations from south of sections D3 and D5 were located very close to the sea ice edge. According to the daily sea ice map from AMSR2 database in Bremen University, the study area near South Orkney Island (SI) was still fully covered by sea ice until Dec 10, 2015, whereas the sea ice had been melted at the other stations at that time. Thus, the following rapid sea ice retreat before the sampling period in sections D5 and D6 near SI strongly affected the surface water. 

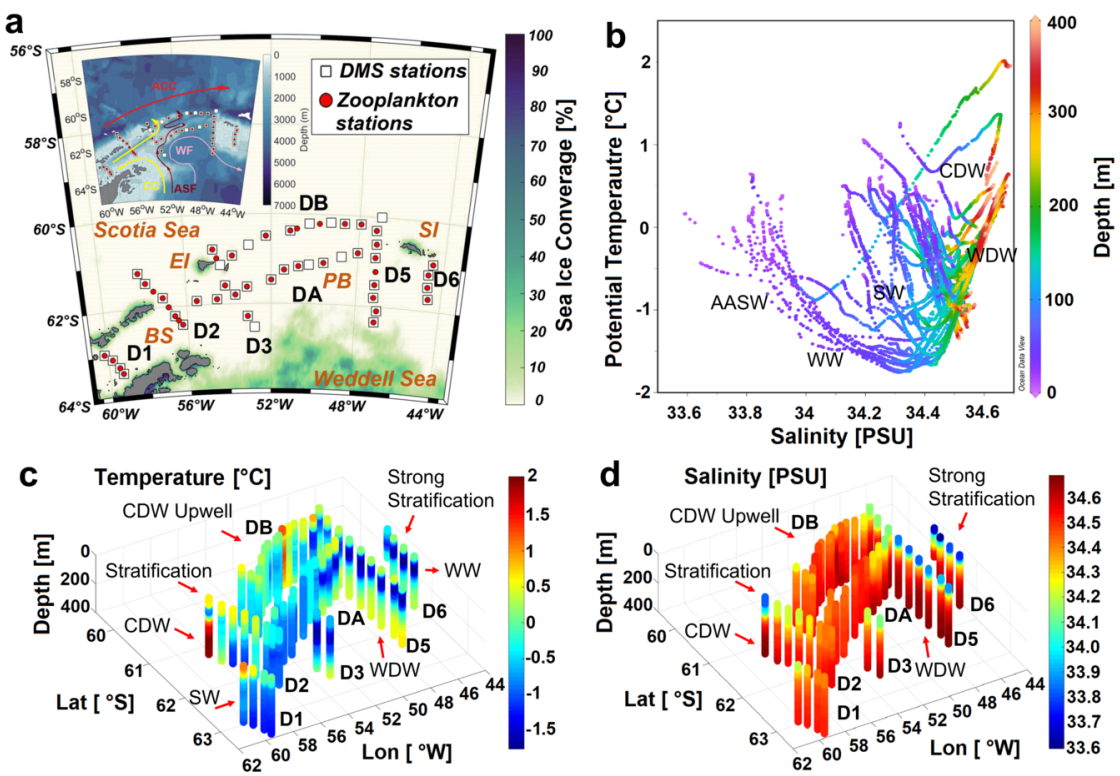

Figure 1. Stations, sea ice distribution and water mass hydrography at the tip of the Antarctic Peninsula during the $32^{\text {nd }}$ Chinese Antarctic Research Expedition. a)Sampling stations for DMS and zooplankton. The mean sea ice coverage during the cruise period is presented in the background. A total of seven sections are marked. The location named BS, EI, PB, SI refer to Bransfield Strait, Elephant Island, Powell Basin and South Orkney Island, respectively. The small plot indicates the currents at the tip of Antarctic Peninsula. The current names of ACC, CC, ASF, WF refer to Antarctic Circumpolar Current, Coast Current, Antarctic Slope Front and Weddell Front, respectively. b) Temperature-Salinity diagram of all stations obtained from the data above $400 \mathrm{~m}$. The water mass names of AASW, WW, SW WDW and CDW refer to Antarctic Summer Water, Winter Water, Shelf water near BS, Warm Deep Water and Circumpolar Deep Water, respectively. c) and d) are the temperature and salinity distributions in the water column. The features of the different water masses are marked with red arrows.

The hydrographic properties in the Scotia Sea and the Weddell Sea have been widely investigated (Palmer et al. 2012). The dominating water masses are presented in Figure $1 \mathrm{~b}$. The warm and high saline current from Weddell Gyre can mix with cool and low saline shelf water from the western area, and subsequently, the mixed water can go north and exchange with Antarctic Circumpolar Current (ACC) in the Scotia Sea through the gaps of South Scotia Ridge (SSR) (Figure 1 c, d) (Palmer et al. 2012). Although our calculation suggested that the mixing layer depth ranged from only $10 \mathrm{~m}$ to $17 \mathrm{~m}$ (Supplementary Figure S1) for all stations, a clear stratification in the upper layer water, which belongs to Antarctic Summer Water (AASW), in sections D5 and D6 near the SI and in northern section D2 at western Elephant Island (EI) was observed. The low saline water there (salinity $<34.1$ ) indicated the strong influence of melting sea ice. In the stations near SI, the water below fresh stratification was the Winter Water (WW), which was colder and formed during the sea ice formation period. Below the WW, the high saline water mass is the Warm Deep Water (WDW) of the Weddell Sea. In the northern DB section, the relatively high salinity (> 34.3) and warm waters indicated the modified upwelling of CDW (Silvester et al. 2014), although this area was not largely affected by upwelling due to the overflowing of currents from the Weddell Sea to the Scotia Sea over the SSR (Naveira Garabatoet al. 2002).

Distributions of seawater DMS and other chemical and biological parameters

The DMS distributions in the euphotic layer of the water column are shown in Figure 2 a. DMS concentrations generally decreased with depth, and the mean level was $6.0 \pm 15.9 \mathrm{nM}$. The highest value of DMS, 85.2 
$\mathrm{nM}$, was consistent with the observations in the marginal ice zone of the Weddell Sea ( $88 \mathrm{nM}$ ) (Fogelqvist 1991) and near $3^{\circ} \mathrm{E}(73.2 \mathrm{nM})$ (Zhanget al. 2017), but much lower than those in coastal polynyas, such as Ross Sea and Amundsen Sea (Tortell et al. 2011; Tortellet al. 2012; Kim et al. 2017). Remarkably, a largescale region of high DMS levels, generally above $40 \mathrm{nM}$, was found in the upper layer waters from sections D5 and D6 near SI. The strong stratification possibly facilitated the production of high seawater DMS. It is necessary to note the slight difference in the vertical DMS distribution between sections D5 and D6 in which the high DMS levels reached $50 \mathrm{~m}$ depth in section D6 but not in D5. Moderate DMS concentrations, from 5 to $10 \mathrm{nM}$, were found in the section D1 and northern stations of D2, which was much higher than those in the previous study at Bransfield Strait (BS) (Berresheim 1987). We also noticed a relatively high DMS concentration, up to $9.3 \mathrm{nM}$, in upper layer water of a station in section $\mathrm{DB}$, where the water mass was likely affected by the modified CDW upwelling (Figure $1 \mathrm{c}, \mathrm{d}$ ). However, in the sections at Powell Basin (PB) and SSR, i.e., sections DA, DB, D2 and D3, respectively, DMS concentrations were generally low (less than $2 \mathrm{nM}$ ). Near the sea ice edge, relatively high DMS concentrations, up to $45.5 \mathrm{nM}$, were observed in the southernmost station of section D3.
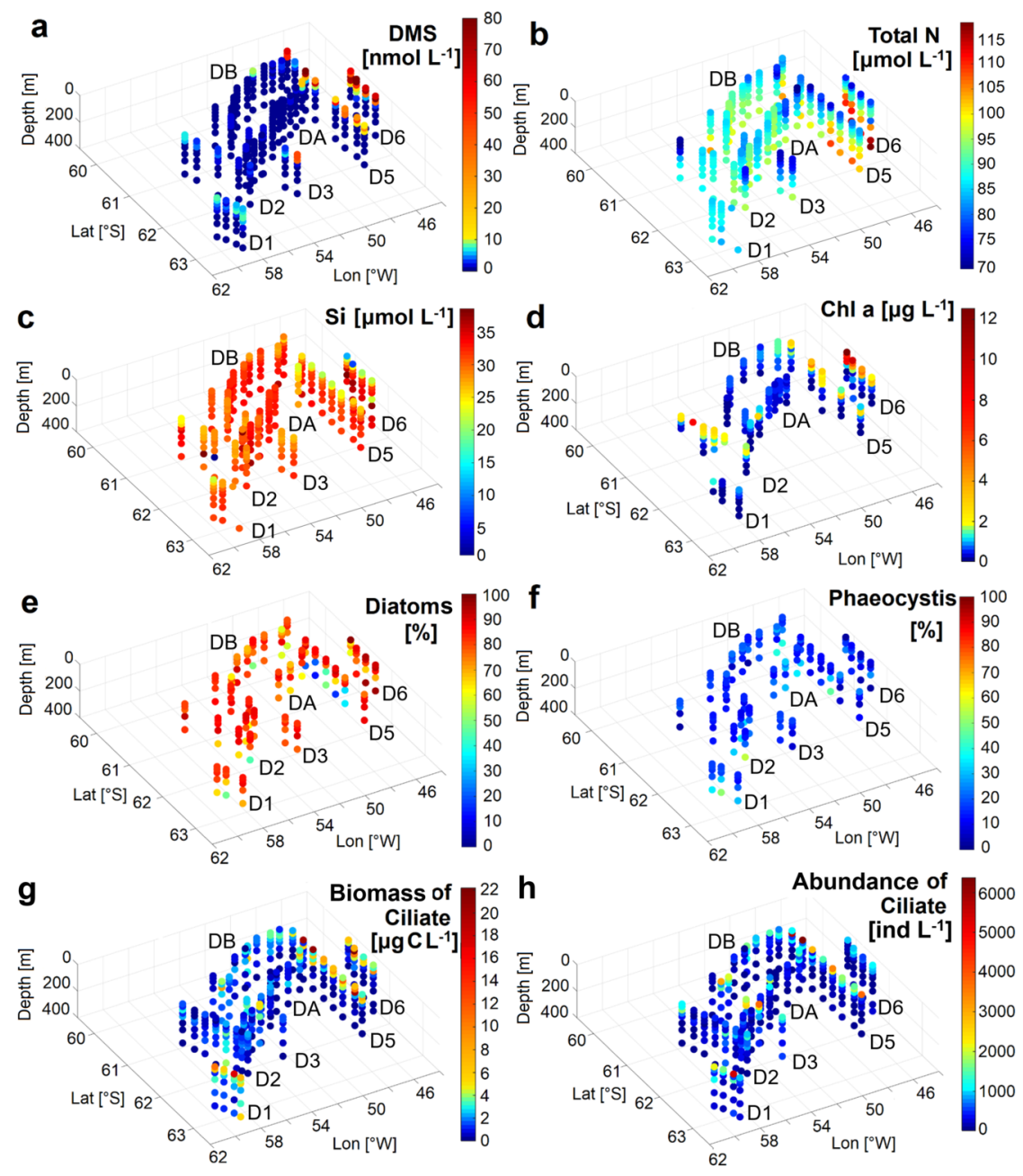

Figure 2. Distributions of the DMS and other chemical and biological parameters in the water column. a) DMS concentrations. b) Total N (sum of nitrate, nitrite and ammonium). c) Silicate. d) $\mathrm{Chl}$ a; Proportion ofe) diatoms and f) phaeocystis in the phytoplankton community; g) Biomass of ciliate; h)Abundance of ciliate; 
The abundance of macronutrients was measured at the tip of the Antarctic Peninsula (Figure $2 \mathrm{~b}$, c, note that phosphate concentrations are shown in Supplementary Figure S2). The levels indicate that macronutrients were sufficient for the growth of phytoplankton. Even in the area of near SI, eastern EI and south of section D3, the strong phytoplankton activity did not cause a significant decrease in the nutrient levels, as the concentrations of total $\mathrm{N}$ (sum of nitrate, nitrite and ammonium) were all above $70 \mu \mathrm{mol} \mathrm{L} \mathrm{L}^{-1}$. Generally, the nutrient levels increased with depth, and high nutrients in upper layer waters occurred in areas with strong dynamics, such as the SSR and PB. These distributions of high nutrient concentrations were possibly strongly affected by the modified upwelling of the CDW and out-spilling of Weddell Sea Deep Water (Naveira et al. 2002; Palmer et al.2012; Silvester et al. 2014).

The distributions of $\mathrm{Chl}$ a, ranging up to $12.5 \mu \mathrm{g} \mathrm{L} \mathrm{L}^{-1}$ and $8.1 \mu \mathrm{g} \mathrm{\textrm {L } ^ { - 1 }}$ near the SI and west of EI, i.e., sections D5, D6 and D2, respectively, suggested that phytoplankton blooms occurred (Figure $2 \mathrm{~d}$ ). These blooms were mainly caused by the growth of diatoms, according to the proportion of different species in the phytoplankton community calculated from pigment data (Figure $2 \mathrm{e}, \mathrm{f}$, see the diagnostic pigment distributions of phytoplankton species in Supplementary Figure S3). It is well known that diatoms can control the blooms during the austral summer in the Southern Ocean (Boyd 2002). The bloom areas are mainly located over the continental shelf regions (Smith \& Comiso 2008), such as those near the SI and western EI. The micronutrients, like iron, are possibly added to the water when it flows over the sediments of the continental shelf and stimulate the growth of phytoplankton (Peloquin \& Smith Jr. 2007). Additionally, sea ice melting likely contributed iron (Wang et al. 2014) and caused the stratification near the SI and western of EI, both of which facilitated the blooms. In most of the other regions, such as BS, PB and SSR, the Chl a values were relatively low $\left(<1 \mu \mathrm{g} \mathrm{L}^{-1}\right)$, indicating a weak phytoplankton activity. This could be due to the lower irradiances available for the phytoplankton inducing greater iron requirements due to greater vertical mixing than those in the shelf regions (Smith \& Comiso 2008). Our study area in the DB section was slightly influenced by the modified upwelling CDW waters, and the supply of iron through this process was possibly not enough to sustain the high phytoplankton biomass. In contrast, large-scale blooms in the Scotia Sea could be observed possibly due to sufficient iron supply from upwelled deep water (Sullivan et al. 1993; de Baaret al. 1995).

Ciliates and heterotrophic dinoflagellates are the dominant microzooplankton species near the Antarctic Peninsula (Garzio \& Steinberg 2013). Here, we present the abundance and biomass of ciliate (Figure $2 \mathrm{~g}, \mathrm{~h}$ ), which is a good indicator of the total microzooplankton distribution in the study area (Garrison 1991). The variation in abundance of ciliate was not completely correlated with the corresponding biomass $\left(\mathrm{R}^{2}=0.41\right.$, $\mathrm{n}=322$; Supplementary Figure S4). The highest abundance of ciliate, up to 6375 ind $\mathrm{L}^{-1}$, associated with

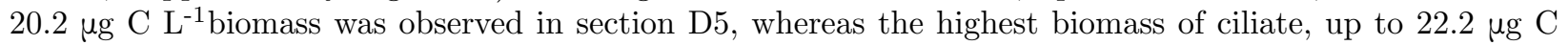
$\mathrm{L}^{-1}$, was found in section D6 with a relatively low abundance of 1122 ind $\mathrm{L}^{-1}$. Generally, the high ciliate abundances, above 2000 ind $\mathrm{L}^{-1}$, were observed in the sections D1, D3 and D5, respectively. The high ciliate biomasses, above $10 \mu \mathrm{g} \mathrm{C} \mathrm{L}{ }^{-1}$, were found in section D1, D5 and D6, respectively. Most areas of the SSR and $\mathrm{PB}$ generally exhibited a relatively low abundance and biomass of ciliate. Notably, the distributions of ciliate were not always consistent with those of phytoplankton biomass. For instance, in the sections D1 and D3, high ciliate biomass or abundance was correlated with low Chl a, whereas the low values correlated with very high phytoplankton biomass in section D2. The possible explanation is the different periods in the growth cycle of both phytoplankton and microzooplankton.

Key role of microzooplankton in triggering extremely high seawater DMS during the phytoplankton bloom

To understand the factors controlling high seawater DMS levels, we investigated the correlations between DMS concentration and several main biological parameters (Table 1). Unsurprisingly, a relatively strong relationship between DMS concentration and Chl a was obtained $(\mathrm{r}=0.781, \mathrm{p}<0.05, \mathrm{n}=174)$. However, the relationship between Chl a and DMS was not always constant. The big fluctuation in DMS concentration corresponding with similar Chl a values was worth to notice, such as the values in section D2 and sections D5, D6 (Figure 2 a, d). Additionally, according to the result that the phytoplankton species dominated by the low-DMSP contained diatom in the upper layer waters of almost all stations (Figure $2 \mathrm{e}, \mathrm{f}$ ), the 
similar phytoplankton biomass suggested an analogy in DMSPp concentrations. Therefore, a possible major explanation for the difference in DMS concentration under the similar phytoplankton biomass there was the discrepancy in releasing DMSPd for producing DMS. The main pathways of releasing DMSPp into the seawater contributing to DMSPd are cell lysis due to algae senescence or viral attack and grazing of zooplankton (Stefels et al. 2007). Based on a time series of the satellite derived MODIS 8-day average Chl a distributions at the tip of the Antarctic Peninsula (Figure 3, b c), it could be seen that the identified blooms, i.e., near the SI and section D2, were both at the beginning stage of rapid phytoplankton growth, as the area coverage and strength of the blooms continued to increase after our study period. Thus, the phytoplankton mortality there was, likely, not mainly caused by senescence or viral attack, but more likely led by the microzooplankton grazing. This is consistent with a previous study showing that microzooplankton grazing is the main cause of phytoplankton mortality in the polar systems (Calbet \& Landry 2004). Actually, microzooplankton in the Southern Ocean can be as plentiful and active as they are in other regions of the world (Garrison 1991), and grazing-deduced DMS production per eaten cell is an order of magnitude higher than those caused by the combination of direct algal release and cell death by viral infection (Evans et al. 2007). It is, thus, reasonable to draw attention to the role of microzooplankton grazing in regulating seawater DMS concentrations in the Southern Ocean.

Table 1, Correlations between DMS and Chl a, ciliate abundance and ciliate biomass in distinct groups. An asterisk indicates that the correlation is significant at the 0.01 level (two tailed). The number of samples is shown below the corresponding correlation. The abbreviations of HH, HL, LH and LL refer to the four identified groups in sections of high phytoplankton biomass $\left(>2 \mathrm{ug} \mathrm{\textrm {L } ^ { - 1 }}\right)$ with high ciliate abundance $\left(>1000\right.$ ind $\left.\mathrm{L}^{-1}\right)$ and biomass $\left(>2 \mathrm{ug} \mathrm{L}^{-1}\right)$, high phytoplankton biomass with low ciliate abundance $(<1000$ ind $\left.\mathrm{L}^{-1}\right)$ and biomass $\left(<2 \mathrm{ug} \mathrm{L}^{-1}\right)$, low phytoplankton biomass $\left(<2 \mathrm{ug} \mathrm{L}^{-1}\right)$ with high ciliate abundance and biomass, and low phytoplankton biomass with low ciliate abundance and biomass.

\begin{tabular}{lllll}
\hline Groups & & Chl a & Ciliate abundance & Ciliate biomass \\
\hline HH & r & $0.818^{*}$ & $0.355^{*}$ & $0.538^{*}$ \\
& & 57 & 95 & 95 \\
HL & r & 0.388 & $0.513^{*}$ & 0.228 \\
& & 19 & 40 & 40 \\
LH & r & 0.120 & 0.261 & $0.504^{*}$ \\
& & 30 & 48 & 48 \\
LL & r & $0.724^{*}$ & $0.409^{*}$ & $0.478^{*}$ \\
& & 68 & 88 & 88 \\
All data & r & $0.781^{*}$ & $0.302^{*}$ & $0.536^{*}$ \\
& & 174 & 271 & 271 \\
\hline
\end{tabular}

However, we could not find strong correlations between the DMS concentration and ciliate abundance and biomass under the all data (Table 1). It is necessary to point out that the low correlations could be explained by the fact that we did not take into account the contributions from other groups of micro-, meso- and macrozooplanktons, such as heterotrophic dinoflagellate, copepods and krill. A higher $\mathrm{r}$ value 0.536 was found between DMS concentration and ciliate biomass than that between DMS and ciliate abundance $(\mathrm{r}=0.302)$. Remarkably, after grouping the sections into four distinct groups, namely the sections of high phytoplankton biomass (Chl a $\left.>2 \mu \mathrm{g} \mathrm{L}^{-1}\right)$ with high ciliate abundance $\left(>1000\right.$ ind $\left.\mathrm{L}^{-1}\right)$ and biomass $\left(>2 \mu \mathrm{g} \mathrm{L} \mathrm{L}^{-1}\right)(\mathrm{HH})$, high phytoplankton biomass with low ciliate abundance $\left(<1000\right.$ ind $\left.\mathrm{L}^{-1}\right)$ and biomass $\left(<2 \mu \mathrm{g} \mathrm{L} \mathrm{L}^{-1}\right)(\mathrm{HL})$, low phytoplankton biomass ( $\mathrm{Chl}$ a $<2 \mu \mathrm{g} \mathrm{\textrm {L } ^ { - 1 }}$ ) with high ciliate abundance and biomass (LH), and low phytoplankton biomass with low ciliate abundance and biomass (LL), we found that extremely high DMS concentrations only occurred under $\mathrm{HH}$ group (Figure 4, using the data above $75 \mathrm{~m}$ ), as in sections D5 and D6, but not in those under either HL (section D2) or LH (sections D1 and D3) (Figure 2 a, d, g, h). As presented in Figure 4, the mean DMS concentation $32.6 \pm 28.2 \mathrm{nM}(\mathrm{n}=52)$ in the HH group was apporixmately 10-fold higher than that in the HL and LH groups, i.e., $3.1 \pm 2.0 \mathrm{nM}(\mathrm{n}=20)$ and $3.4 \pm 2.6 \mathrm{nM}$ 
$(\mathrm{n}=36)$, respectivley, and about 30-folds higher than that of $1.1 \pm 1.5 \mathrm{nM}(\mathrm{n}=68)$ in LL group. Additionally, we could not find strong correlations between DMS and Chl a, ciliate abundance and biomass in each distinct group except those between DMS and Chl a in HH and LL group (Table 1). Also, the correlations between DMS and ciliate biomass were generally higher than those between DMS and ciliate abundance in each separated groups.
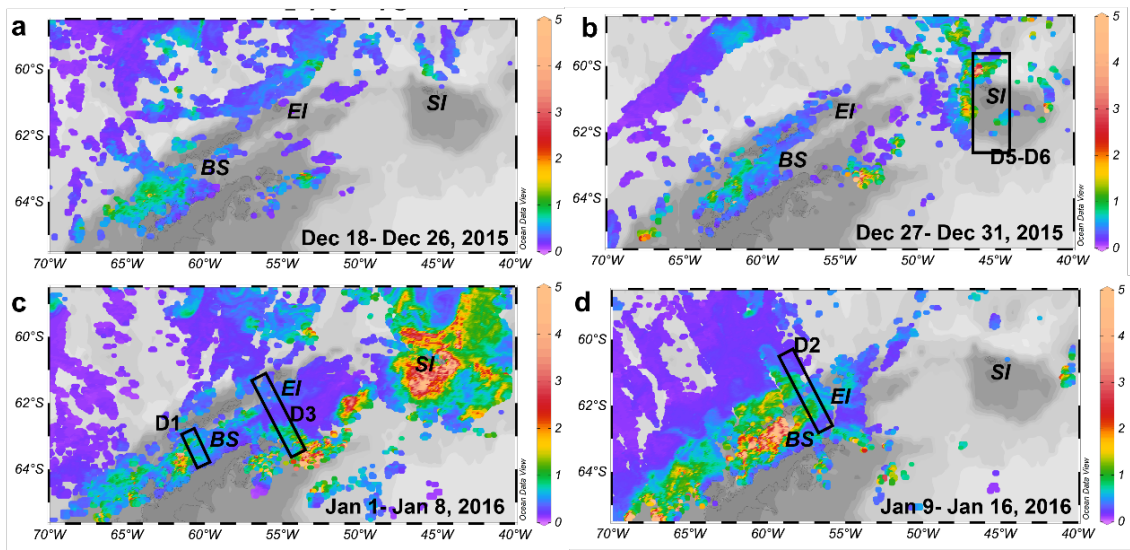

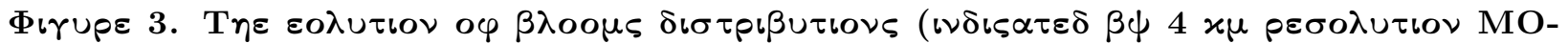

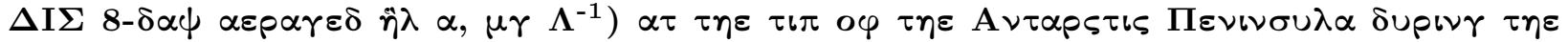
$\varepsilon \xi \pi \varepsilon \delta \iota \tau \iota \mathbf{\nu ~} \pi \varepsilon \rho\llcorner\mathbf{o} . \boldsymbol{\alpha})$ From Dec 18 to Dec 26, 2015. b) From Dec 27 to Dec 31, 2015. c) From Jan 1 to Jan 8, 2016. d) From Jan 9 to Jan 16, 2016. Note that the locations of selected sections were marked with rectangles. The sampling periods of the marked sections are consistent with those selected MODIS plots. The Chl a values are capped at $5 \mu \mathrm{g} \mathrm{L} \mathrm{L}^{-1}$

Another aspect that is worth noting is the grazing mortality rate of phytoplankton. According to a previous study near the Antarctic Peninsula in January of 2009 to 2011, although a grazing mortality rate of phytoplankton of $0.24 \mathrm{~d}^{-1}$ (Garzio et al.2013) was much lower than those in tropical and temperate habitats, 0.72 and $0.69 \mathrm{~d}^{-1}$, respectively (Calbet \& Landry 2004), the magnitude of microzooplankton could also contribute to the large grazing mortality of phytoplankton during the bloom. The released abundant DMSP caused by the grazing might be accumulated in the stratificated upper layer waters (Figure $1 \mathrm{c}, \mathrm{d}$ ). Also, the strong stratification could facilitate the accumulation and growth of both microzooplankton and phytoplankton and, thus, in turn, enhance the DMSP release and DMS production (Simó \& Pedrósalió 1999). The enhancement in DMS production was likely mainly caused by the developing bacterial community corresponding with the expanding blooms (Figure 3), and a relatively large proportion of DMSP might be rapidly converted into DMS (Stefels et al. 2007). Additionally, the slow pathway of the dominant removal pathway of DMS, i.e., biological consumption (Del Valleet al. 2009), might also facilitate the accumulation of DMS in the upper layer waters. The DMS photolysis rate was also possibly not strong during our sampling period, while its high values more likely occurred under the non-bloom and free ice condition (Toole et al.2004). Thus, the high DMS production and the low removal of DMS may also explain the findings of observed extremely high DMS values during the blooms. 

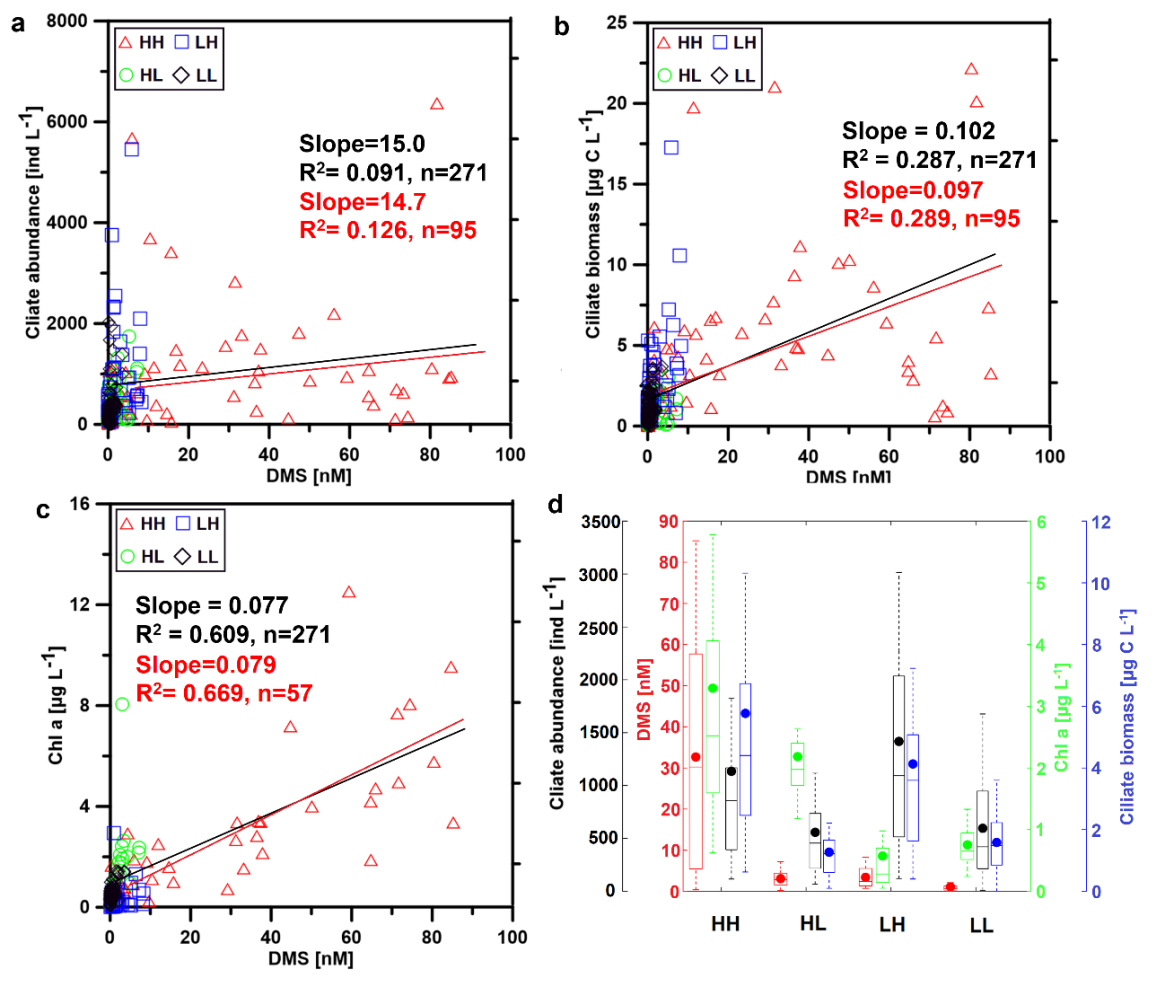

Figure 4. Extremely high seawater DMS was only found in areas with co-existing phytoplankton blooms and abundant microzooplankton. The comparison of seawater DMS, ciliate and Chl a mean and median values (indicated by the dots and line in the box respectively) in the four identified regions in the upper layer waters $(0-75 \mathrm{~m})$. The abbreviations of HH, HL, LH and LL refer to the four identified groups in sections of high phytoplankton biomass $\left(>2 \mathrm{ug} \mathrm{L}^{-1}\right)$ with high ciliate abundance $(>1000$ ind $\mathrm{L}$

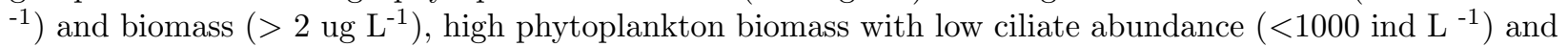
biomass $\left(<2 \mathrm{ug} \mathrm{L}^{-1}\right)$, low phytoplankton biomass $\left(<2 \mathrm{ug} \mathrm{L}^{-1}\right)$ with high ciliate abundance and biomass, and low phytoplankton biomass with low ciliate abundance and biomass. Note that interquartile range are indicated by the boundary of the boxes and the whisker dashed line indicates the 1 time interquartile range. To ensure the readability of plots, the outlier data points were not presented.

\section{Conclusions and implications}

In this study, we have shown that the co-existence of phytoplankton blooms and abundant microzooplankton was found to be a critical factor controlling extremely high seawater DMS concentrations. The phytoplankton bloom is likely the prerequisite, and an increase in zooplankton growth often follows with increasing phytoplankton. Thus, understanding the distributions of blooms (Sullivan et al. 1993) are of great importance for evaluating the high seawater DMS levels over the Southern Ocean. Another aspect we want to highlight is that the Southern Ocean environment has experienced the pressures from climate change over the past decades (Jones et al. 2016), including ocean warming and freshening (Swart et al. 2018), abnormal variations in sea ice extent (Meehl et al. 2019) and decline of ice sheet (Shepherd et al. 2018) etc, and these types of changes are expected to continue and, perhaps, be enhanced in the future (Chown \& Brooks 2019). Undoubtedly, these changes can affect the ecosystems in the Southern Ocean (Montes-Hugo et al. 2009). For instance, the melting of ice shelf can input a large flux of iron to sustain the large annual phytoplankton blooms (Herraiz-Borreguero et al. 2016); warming and iron enrichment can affect the bloom-forming polar species (Boyd et al. 2016; Boyd 2019); warming and ocean acidification might also alter the zooplankton grazing rate and community structure (Kim et al. 2010; Park et al. 2014; Hammill et al.2018). The corre- 
sponding changes in the blooms and microzooplankton in the Southern Ocean will influence the production of extremely high seawater DMS as well, which possibly impacts regional particle formation, clouds, and the radiative balance (Meskhidze \& Nenes 2006). Thus, it is worthwhile to perform future studies to investigate these important Southern Ocean climate feedbacks.

\section{Acknowledgements}

We thank the Chinese Arctic and Antarctic Administration (CAA) of the Ministry of Natural Resources and the crew of R/V Xue Long for their support with field operations. We thank the Dr Christa. A. Marandino for her kindness giving the useful comments and revising the manuscript. We thank Dr Qiang Hao who measured and provided the Chl a data during the expedition. We thank the Institute of Environmental Physics, University of Bremen for the provision of the merged MODIS-AMSR2 sea-ice concentration data at https://seaice.uni-bremen.de/data/modis_amsr2. We want to thank Mrs Na Li for her kind help with plotting. Our datasets are currently included in the Supporting Information as Dataset S1 and will be uploaded to the PMEL repository after this paper is published. This work was supported by the Scientific Research Foundation of Third Institute of Oceanography, at the Ministry of Natural Resources (under contract No. 2019009, No. 2018014, 2019008), the National Natural Science Foundation of China (NSFC) $(42076226,41706104,41976228,41911540471)$, the international cooperation program managed by the National Research Foundation of Korea (NRF-2019K2A9A2A06025329), the Ministry of Science and Technology and Key Research \& Development Programs (No. 2018YFC1406703), the Chinese Projects for Investigations and Assessments of the Arctic and Antarctic, the International Organizations and Conference and Bilateral Cooperation of Maritime Affairs, the Chinese Projects for Investigations and Assessments of the Arctic and Antarctic (CHINARE2017-2020), the response and feedback of the Southern Ocean to climate change (RFSOCC2020-2025), the Korean Polar Research Institute (Grant PE20140), and Grant. No. DY135-B2-13 from China Ocean Mineral Resources R\&D Association (project No. 2018N2001).

\section{Competing interests}

The authors declare no competing interests.

\section{Supplementary information}

Figure S1. The calculated mixing layer depth in the study area.

Figure S2. Distributions of $\mathrm{PO}_{4}^{3-}(\mathrm{P})$ at the tip of the Antarctic Peninsula.

Figure S3, The diagnostic pigment distributions of a) diatoms and b)phaeocystis at the tip of Antarctic Peninsula

Figure S4. Relationship between the number and weight of ciliate in the study area.

\section{References}

Archer S.D., Stelfox-Widdicombe C.E., Burkill P.H. \& Malin G. (2001a). A dilution approach to quantify the production of dissolved dimethylsulphoniopropionate and dimethyl sulphide due to microzooplankton herbivory. Aquat. Microb. Ecol. , 23, 131-154.

Archer S.D., Widdicombe C.E., Tarran G.A., Rees A.P. \& Burkill P.H. (2001b). Production and turnover of particulate dimethylsulphoniopropionate during a coccolithophore bloom in the northern North Sea. Aquat. Microb. Ecol. , 24, 225-241.

Arrigo K.R. \& van Dijken G.L. (2003). Phytoplankton dynamics within 37 Antarctic coastal polynya systems.J. Geophys. Res. Oceans, 108, 3271.

Arrigo K.R., Worthen D., Schnell A. \& Lizotte M.P. (1998). Primary production in Southern Ocean waters.J. Geophys. Res. Oceans, 103, 15587-15600.

Arrigo K.R., Worthen D.L., Lizotte M.P., Dixon P. \& Dieckmann G. (1997). Primary Production in Antarctic Sea Ice. Science, 276, 394-397. 
Asher E.C., Dacey J.W.H., Mills M.M., Arrigo K.R. \& Tortell P.D. (2011). High concentrations and turnover rates of DMS, DMSP and DMSO in Antarctic sea ice. Geophy. Res. Lett., 38, L23609.

Atkinson A., Siegel V., Pakhomov E. \& Rothery P. (2004). Long-term decline in krill stock and increase in salps within the Southern Ocean. Nature, 432, 100-103.

Ayers G.P. \& Gillett R.W. (2000). DMS and its oxidation products in the remote marine atmosphere: implications for climate and atmospheric chemistry. J. Sea. Res ., 43, 275-286.

Berresheim H. (1987). Biogenic sulfur emissions from the Subantarctic and Antarctic Oceans. J. Geophys. Res. , 92, 13245-13,262.

Boyd P.W. (2002). Environmental factors controlling phytoplankton processes in the Southern Ocean. $J$ Phycol., 38, 844-861.

Boyd P.W. (2019). Physiology and iron modulate diverse responses of diatoms to a warming Southern Ocean.Nat. Clim. Change, 9, 148-152.

Boyd P.W., Dillingham P.W., McGraw C.M., Armstrong E.A., Cornwall C.E., Feng Y.y., et al., , TimminsSchiffman E. \& Nunn B.L. (2016). Physiological responses of a Southern Ocean diatom to complex future ocean conditions. Nat. Clim. Change, , 6, 207-213.

Boyd P.W., Watson A.J., Law C.S., Abraham E.R., Trull T., Murdoch R., et al. , (2000). A mesoscale phytoplankton bloom in the polar Southern Ocean stimulated by iron fertilization. Nature, 407, 695-702.

Calbet A. \& Landry M.R. (2004). Phytoplankton growth, microzooplankton grazing, and carbon cycling in marine systems. Limnol. Oceanogr., 49, 51-57.

Charlson R.J., Lovelock J.E., Andreae M.O. \& Warren S.G. (1987). Oceanic phytoplankton, atmospheric sulphur, cloud albedo and climate. Nature, 326, 655-661.

Chavez F.P. \& Messié M. (2009). A comparison of Eastern Boundary Upwelling Ecosystems. Prog. Oceanogr. , 83, 80-96.

Chown S.L. \& Brooks C.M. (2019). The State and Future of Antarctic Environments in a Global Context.Annu. Rev. Env. Resour., 44, 1-30.

Dacey J.W.H., Wakeham, Stuart G. (1986). Oceanic Dimethylsulfide: Production During Zooplankton Grazing on Phytoplankton. Science, 233, 1314-1316.

de Baar H.J.W., de Jong J.T.M., Bakker D.C.E., Loscher B.M., Veth C., Bathmann U. et al. ,. (1995). Importance of iron for plankton blooms and carbon dioxide drawdown in the Southern Ocean. Nature, 373, 412-415.

Del Valle D.A., Kieber D.J., Toole D.A., Brinkley J. \& Kiene R.P. (2009). Biological consumption of dimethylsulfide (DMS) and its importance in DMS dynamics in the Ross Sea, Antarctica. Limnol. Oceanogr. , 54, 785-798.

Deschaseaux E., Jones G. \& Swan H. (2016). Dimethylated sulfur compounds in coral-reef ecosystems.Environ. Chem., 13, 239-251.

Evans C., Kadner S.V., Darroch L.J., Wilson W.H., Liss P.S. \& Malin G. (2007). The relative significance of viral lysis and microzooplankton grazing as pathways of dimethylsulfoniopropionate (DMSP) cleavage: An Emiliania huxleyi culture study. Limnol. Oceanogr. , 52, 1036-1045.

Fogelqvist E. (1991). Dimethylsulphide (DMS) in the Weddell Sea surface and bottom water.Mar. Chem. , $35,169-177$.

Garrison D.L. (1991). An overview of the abundance and role of protozooplankton in Antarctic waters. $J$ Marine Syst. , 2, 317-331. 
Garzio L.M. \& Steinberg D.K. (2013). Microzooplankton community composition along the Western Antarctic Peninsula. Deep Sea Res. Part I: Oceanogr. Res. Pap., 77, 36-49.

Garzio L.M., Steinberg D.K., Erickson M. \& Ducklow H.W. (2013). Microzooplankton grazing along the Western Antarctic Peninsula. Aquat. Microb. Ecol., 70, 215-232.

Grasshoff K., Kremling K. \& Ehrhardt M. (2009). Methods of seawater analysis . John Wiley \& Sons.

Hammill E., Johnson E., Atwood T.B., Harianto J., Hinchliffe C., Calosi P. et al., (2018). Ocean acidification alters zooplankton communities and increases top-down pressure of a cubozoan predator. Global Change Biol., 24, e128-e138.

Herraiz-Borreguero L., Lannuzel D., van der Merwe P., Treverrow A. \& Pedro J.B. (2016). Large flux of iron from the Amery Ice Shelf marine ice to Prydz Bay, East Antarctica.J Geophy. Res. Oceans, 121, 6009-6020.

Inomata Y., Hayashi M., Osada K. \& Iwasaka Y. (2006). Spatial distributions of volatile sulfur compounds in surface seawater and overlying atmosphere in the northwestern Pacific Ocean, eastern Indian Ocean, and Southern Ocean. Global Biogeochem. Cycles, 20, GB2022.

Jones J.M., Gille S.T., Goosse H., Abram N.J., Canziani P.O., Charman D.J. et al. , (2016). Assessing recent trends in high-latitude Southern Hemisphere surface climate.Nat. Clim. Change, 6, 917-926.

Kasamatsu N., Kawaguchi S., Watanabe S., Odate T. \& Fukuchi M. (2004). Possible impacts of zooplankton grazing on dimethylsulfide production in the Antarctic Ocean. Can. J. Fish. Aquat. Sci., 61, 736-743.

Kim I., Hahm D., Park K., Lee Y., Choi J.O., Zhang M., et al., (2017). Characteristics of the horizontal and vertical distributions of dimethyl sulfide throughout the Amundsen Sea Polynya. Sci. Total Environ. , 584-585, 154.

Kim J.-M., Lee K., Yang E.J., Shin K., Noh J.H., Park K.-t. et al. , (2010). Enhanced Production of Oceanic Dimethylsulfide Resulting from $\mathrm{CO}_{2}$-Induced Grazing Activity in a High $\mathrm{CO}_{2}$ World. Environ. Sci. Technol., $44,8140-8143$.

Lana A., Bell T., Simó R., Vallina S.M., Ballabrera-Poy J., Kettle A., et al. , (2011). An updated climatology of surface dimethlysulfide concentrations and emission fluxes in the global ocean. Global Biogeochem. Cycles , 25, GB1004.

Liang C., Li H., Dong Y., Zhao Y., Tao Z., Li C., et al. , (2018). Planktonic ciliates in different water masses in open waters near Prydz Bay (East Antarctica) during austral summer, with an emphasis on tintinnid assemblages. Polar Biol. , 41, 2355-2371.

Liss P.S., Marandino C.A., Dahl E.E., Helmig D., Hintsa E.J., Hughes C., et al. , (2014). Short-lived trace gases in the surface ocean and the atmosphere. In:Ocean-Atmosphere Interactions of Gases and Particles . Springer, pp. 1-54.

Mackey M.D., Mackey D.J., Higgins H.W. \& Wright S.W. (1996). CHEMTAX - a program for estimating class abundances from chemical markers: application to HPLC measurements of phytoplankton. Mar. Ecol. Prog. Ser., 144, 265-283.

McCoy D.T., Burrows S.M., Wood R., Grosvenor D.P., Elliott S.M., Ma P.-L., et al., (2015). Natural aerosols explain seasonal and spatial patterns of Southern Ocean cloud albedo. Sci. Adv. , 1, e1500157.

Meehl G.A., Arblaster J.M., Chung C.T.Y., Holland M.M., DuVivier A., Thompson L., et al. , (2019). Sustained ocean changes contributed to sudden Antarctic sea ice retreat in late 2016. Nature Commun., 10, 14.

Meskhidze N. \& Nenes A. (2006). Phytoplankton and cloudiness in the Southern Ocean. Science , 314, 1419-1423. 
Montes-Hugo M., Doney S.C., Ducklow H.W., Fraser W., Martinson D., Stammerjohn S.E. et al. , (2009). Recent Changes in Phytoplankton Communities Associated with Rapid Regional Climate Change Along the Western Antarctic Peninsula.Science, 323, 1470-1473.

Naveira Garabato A.C., Heywood K.J. \& Stevens D.P. (2002). Modification and pathways of Southern Ocean Deep Waters in the Scotia Sea. Deep Sea Res. Part I: Oceanogr. Res. Pap., 49, 681-705.

Nevitt G.A., Veit R.R. \& Kareiva P. (1995). Dimethyl sulphide as a foraging cue for Antarctic Procellariiform seabirds. Nature, 376, 680-682.

Palmer M., Gomis D., Flexas M.d.M., Jordà G., Jullion L., Tsubouchi T., et al. , (2012). Water mass pathways and transports over the South Scotia Ridge west of $50^{\circ} \mathrm{W}$.Deep Sea Res. Part I: Oceanogr. Res. Pap. , 59, 8-24.

Park K.-T., Lee K., Shin K., Yang E.J., Hyun B., Kim J.-M., et al. , (2014). Direct Linkage between Dimethyl Sulfide Production and Microzooplankton Grazing, Resulting from Prey Composition Change under High Partial Pressure of Carbon Dioxide Conditions. Environ. Sci. Technol. , 48, 4750-4756.

Peloquin J.A. \& Smith Jr. W.O. (2007). Phytoplankton blooms in the Ross Sea, Antarctica: Interannual variability in magnitude, temporal patterns, and composition. J Geophy. Res. Oceans, 112.

Quinn P. \& Bates T. (2011). The case against climate regulation via oceanic phytoplankton sulphur emissions. Nature , 480, 51-56.

Quinn P.K., Coffman D.J., Johnson J.E., Upchurch L.M. \& Bates T.S. (2017). Small fraction of marine cloud condensation nuclei made up of sea spray aerosol. Nature Geosci.,10, 674.

Shepherd A., Ivins E., Rignot E., Smith B., van den Broeke M., Velicogna I., et al. , (2018). Mass balance of the Antarctic Ice Sheet from 1992 to 2017. Nature, 558, 219-222.

Silvester J.M., Lenn Y.-D., Polton J.A., Rippeth T.P. \& Maqueda M.M. (2014). Observations of a diapycnal shortcut to adiabatic upwelling of Antarctic Circumpolar Deep Water.Geophys. Res. Lett. , 41, 7950-7956.

Simó R. \& Pedrósalió C. (1999). Role of vertical mixing in controlling the oceanic production of dimethyl sulphide. Nature , 402, 396-399.

Smith W.O. \& Comiso J.C. (2008). Influence of sea ice on primary production in the Southern Ocean: A satellite perspective. J Geophy. Res. Oceans, 113, C05S93.

Stefels J., Steinke M., Turner S., Malin G. \& Belviso S. (2007). Environmental constraints on the production and removal of the climatically active gas dimethylsulphide (DMS) and implications for ecosystem modelling. Biogeochemistry , 83, 245-275.

Sullivan C., Arrigo K., McClain C., Comiso J. \& Firestone J. (1993). Distributions of phytoplankton blooms in the Southern Ocean. Science, 262, 1832-1837.

Swart N.C., Gille S.T., Fyfe J.C. \& Gillett N.P. (2018). Recent Southern Ocean warming and freshening driven by greenhouse gas emissions and ozone depletion. Nature Geosci. , 11, 836-841.

Tang K.W., Dam H.G., Visscher P.T. \& Fenn T.D. (1999). Dimethylsulfoniopropionate (DMSP) in marine copepods and its relation with diets and salinity. Mar. Ecol. Prog. Ser.,179, 71-79.

Toole D.A., Kieber D.J., Kiene R.P., White E.M., Bisgrove J., del Valle D.A. et al. , (2004). High dimethylsulfide photolysis rates in nitrate-rich Antarctic waters.Geophys. Res. Lett., 31, L11307.

Tortell P., Gueguen C., Long M., Payne C., Lee P. \& DiTullio G. (2011). Spatial variability and temporal dynamics of surface water pCO2,[Delta] O2/Ar and dimethylsulfide in the Ross Sea, Antarctica. Deep Sea Res. Part I: Oceanogr. Res. Pap., 58, 241-259. 
Tortell P.D., Long M.C., Payne C.D., Alderkamp A.C., Dutrieux P. \& Arrigo K.R. (2012). Spatial distribution of $\mathrm{pCO}_{2}, \Delta \mathrm{O}_{2} / \mathrm{Ar}$ and dimethylsulfide (DMS) in polynya waters and the sea ice zone of the Amundsen Sea, Antarctica. Deep Sea Res. Part II: Top. Stud. Oceanogr., 71-76, 77-93.

Van Alstyne K.L. \& Houser L.T. (2003). Dimethylsulfide release during macroinvertebrate grazing and its role as an activated chemical defense. Mar. Ecol. Prog. Ser. , 250, 175-181.

Wang S., Bailey D., Lindsay K., Moore J.K. \& Holland M. (2014). Impact of sea ice on the marine iron cycle and phytoplankton productivity. Biogeosciences, 11, 4713-4731.

Wolfe G.V. \& Steinke M. (1996). Grazing-activated production of dimethyl sulfide (DMS) by two clones of Emiliania huxleyi. Limnol. Oceanogr. , 41, 1151-1160.

Yang G.-P., Zhuang G.-C., Zhang H.-H., Dong Y. \& Yang J. (2012). Distribution of dimethylsulfide and dimethylsulfoniopropionate in the Yellow Sea and the East China Sea during spring: Spatio-temporal variability and controlling factors.Mar. Chem., 138, 21-31.

Zhang M. \& Chen L. (2015). Continuous underway measurements of dimethyl sulfide in seawater by purge and trap gas chromatography coupled with pulsed flame photometric detection. Mar. Chem. , 174, 67-72.

Zhang M., Marandino C.A., Chen L., Sun H., Gao Z., Park K., et al. , (2017). Characteristics of the surface water DMS and pCO2 distributions and their relationships in the Southern Ocean, southeast Indian Ocean, and northwest Pacific Ocean. Global Biogeochem. Cycles , 31, 1318-1331.

Zhuang Y., Jin H., Li H., Chen J., Lin L., Bai Y., Ji Z., Zhang Y. \& Gu F. (2016). Pacific inflow control on phytoplankton community in the Eastern Chukchi Shelf during summer.Cont. Shelf Res. , 129, 23-32.
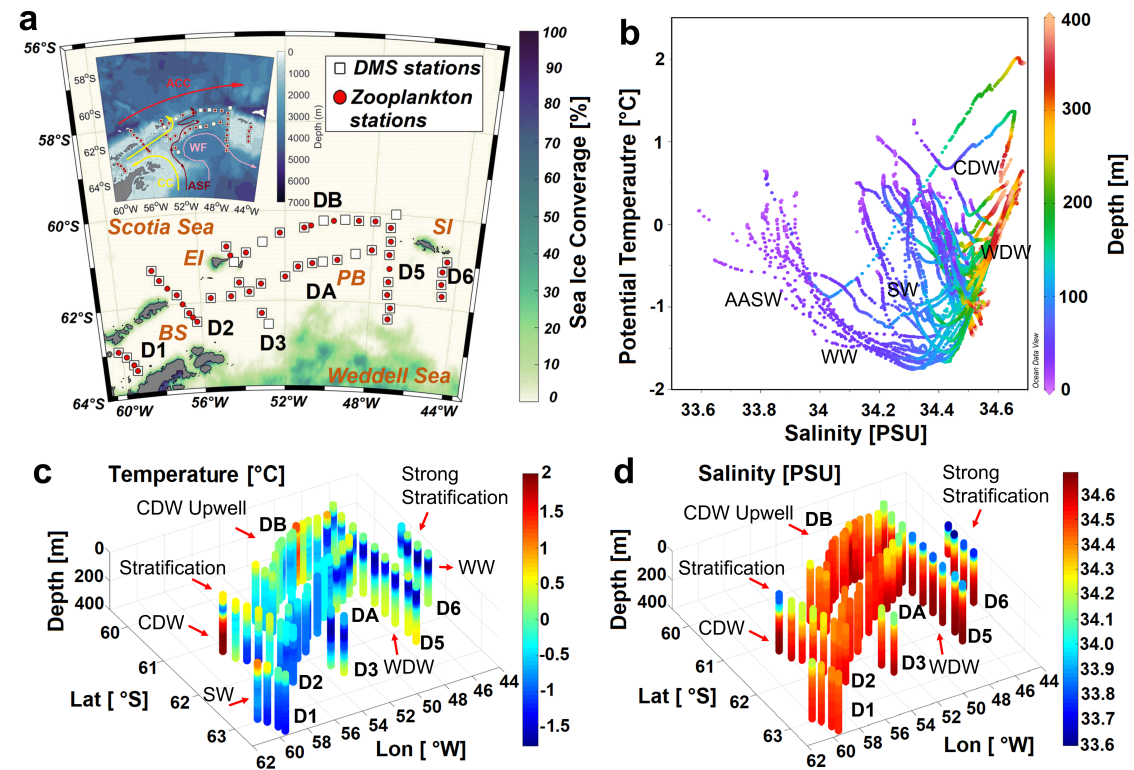

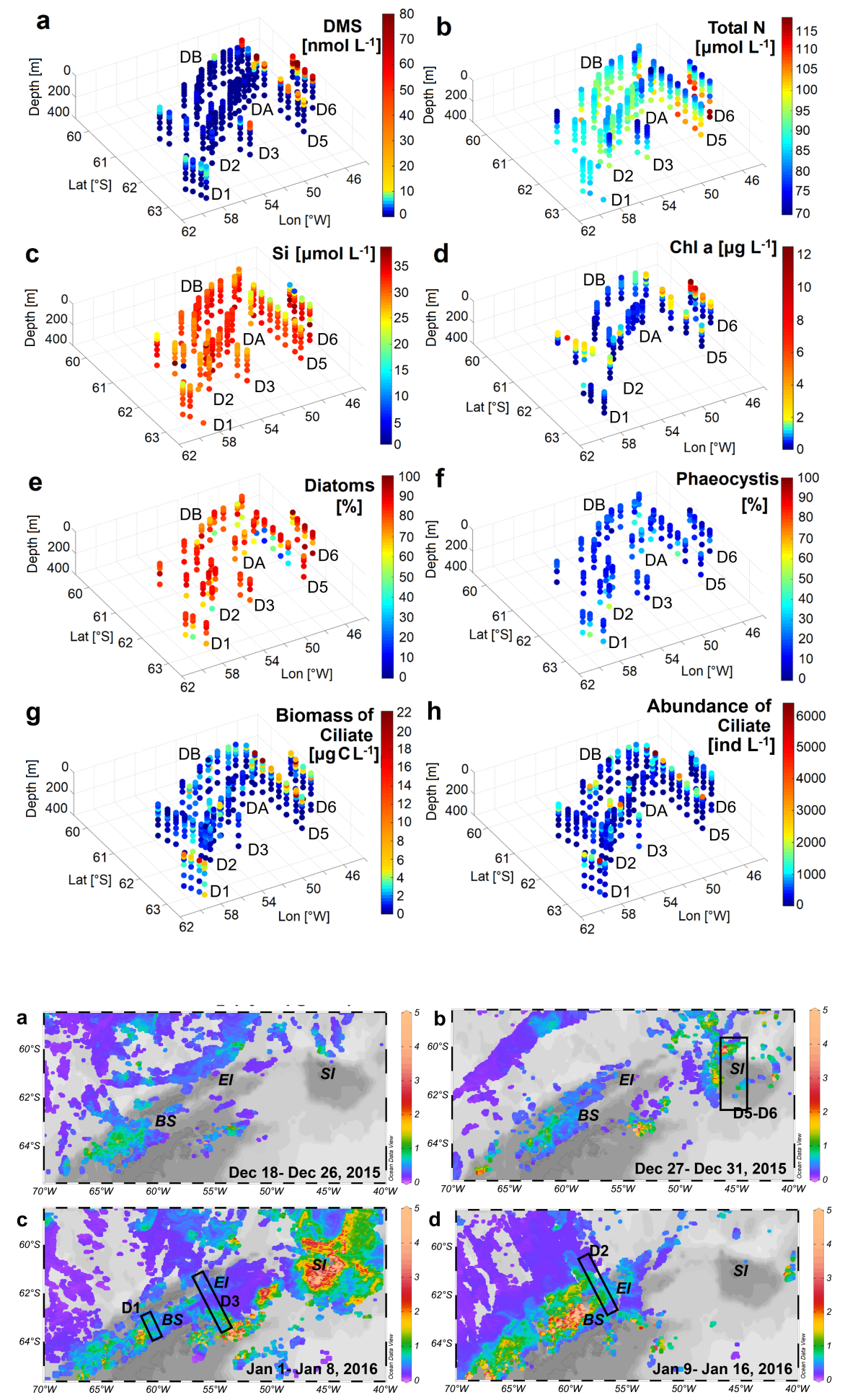


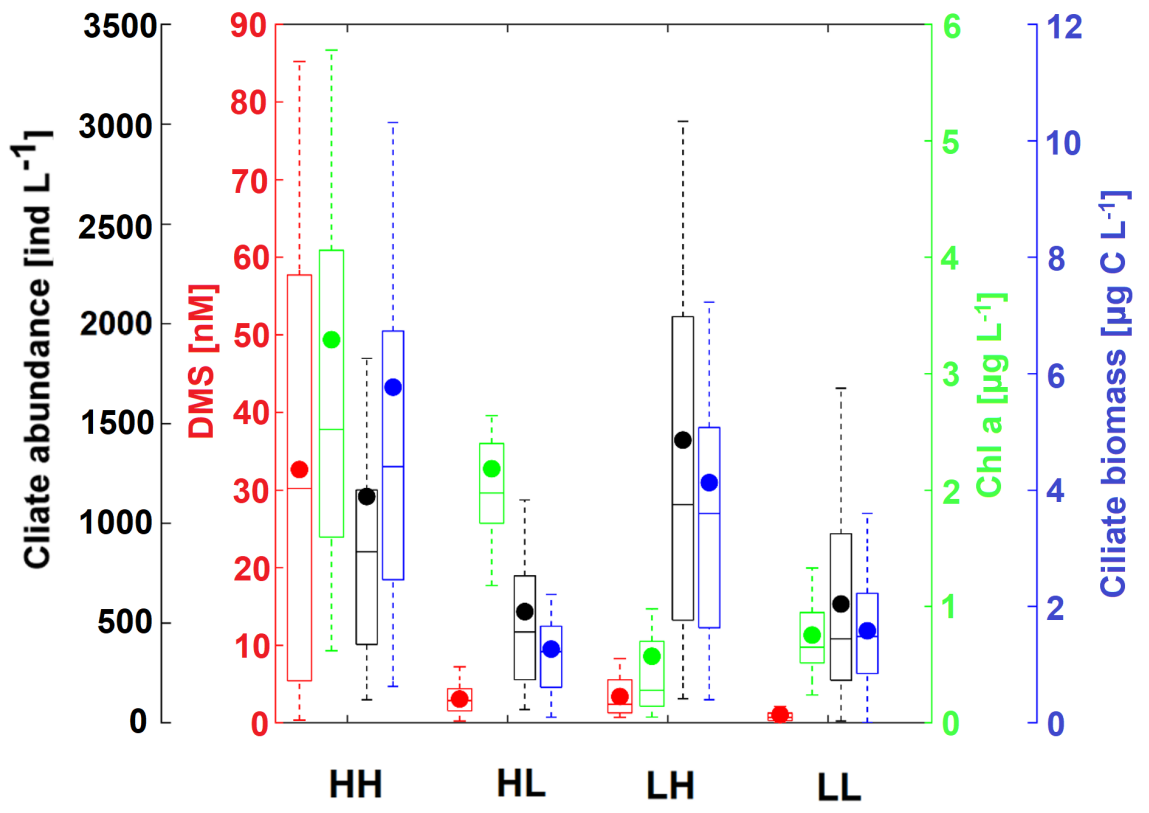

